引用格式: 张金茜,柳冬青, 巩杰, 等. 流域景观破碎化对土壤保持服务的影响研究一一甘肃白龙江流域为例[J]. 资源科学, 2018, 40 (9) : 1866-1877. [Zhang J X, Liu D Q, Gong J, et al. Impact of landscape fragmentation on watershed soil conservation servicea case study on Bailongjiang Watershed of Gansu[J]. Resources Science, 2018,40(9) : 1866-1877.] DOI : 10.18402/resci.2018.09.16

\title{
流域景观破碎化对土壤保持服务的影响研究 以甘肃白龙江流域为例
}

\author{
张金茜, 柳冬青, 巩 杰,马学成, 曹二佳 \\ （兰州大学资源环境学院/西部环境教育部重点实验室, 兰州 730000)
}

\begin{abstract}
摘＼cjkstart要:甘肃白龙江流域是中国四大滑坡和泥石流灾害高发区之一,也是长江上游重要的水源涵养区和生态 脆弱区, 土壤保持服务尤为重要,近几十年来日益增强的人类活动不仅加重了土壤侵蚀,也加剧了景观破碎化, 因 此开展景观破碎化对土壤保持服务的影响研究可以明晰两者间的空间关联, 旨在为流域生态系统的可持续发展提 供科学依据。本文综合运用景观格局指数、网格分析和双变量空间自相关等方法, 揭示了 1990-2014年甘肃白龙 江流域景观破碎化与土壤保持服务的时空格局, 并从数理统计和空间统计两个角度探讨了两者间的相关关系。结 果表明: (1) 1990-2014年甘肃白龙江流域景观破碎化程度和土壤保持服务分别呈现先增后减、先降后升的变化趋 势; (2) 1990-2014年间，甘肃白龙江流域土壤保持服务与景观破碎化的空间负相关关系从无到有，且两者间的空间 关联性逐渐增强; (3) 2014 年宕昌北部、武都中南部及最南端、文县南部和宕昌-舟曲-武都交汇处的景观破碎化程度 对该区土壤保持服务产生显著负影响,可通过减弱景观破碎化以达到提升土壤保持服务的目的。
\end{abstract}

关键词: 景观格局; 景观破碎化; 土壤保持服务;甘肃白龙江流域

DOI : 10.18402/resci.2018.09.16

\section{1 引言}

地表景观格局一直处于变化之中, 这是景观 内、外部各因素在不同时空尺度上作用的结果 ${ }^{[1]}$ 。 随着人类活动的不断增强及工业化和城市化, 地表 景观变化日趋剧烈, 景观破碎化尤为显著 ${ }^{[2]}$, 直接影 响着景观中能量流动与物质循环等生态过程 ${ }^{[3]}$ 。因 此, 景观破碎化越来越受到广大学者的关注, 成为 景观生态学重要的研究热点之一 ${ }^{[4]}$ 。近年来, 国内 外学者一直致力于景观破碎化时空格局特征与其 驱动因子 ${ }^{[5-7]}$ 、对生物多样性及栖息地 ${ }^{[8-10]}$ 的影响及景 观破碎化对生态系统过程和功能的影响研究 ${ }^{[1,12]}$ 等。其中, 景观破碎化通过改变生态系统组分、结 构与生态过程及生物多样性等对生态系统服务产 生重要影响 ${ }^{[13,14]}$ 。生态系统服务是生态系统结构及
其生态过程所形成和维持的人类赖以生存和发展 的自然效用 ${ }^{[15,16]}$, 与人类福祉息息相关,生态系统服 务的退化将威胁到区域乃至全球的生态系统安全 ${ }^{[17]}$, 而景观破碎化是导致生态系统服务弱化的主要原 因 ${ }^{[18]}$ 。因此, 探讨景观破碎化对生态系统服务的影 响及其内在机制、生态服务功能对其景观变化的响 应、以及如何保持生态系统的生命支持功能是区域 可持续发展研究的重要课题 ${ }^{[17]}$ 。

土壤保持服务是生态系统对土壤侵蚀所起到 的削减和抑制效用的总称, 在土壤流失防治和土地 生产力保育中起着关键作用 ${ }^{[19]}$, 作为重要的生态系 统服务类型之一, 是区域土壤形成、植被固着、水源 涵养等功能的重要基础,已成为全球变化领域的研 究热点之一 ${ }^{[16]}$ 。目前, 土壤保持服务常用土壤保持

收稿日期: 2017-10-31; 修订日期: 2018-03-11

基金项目: 国家自然科学基金面上项目(41771196、41271199)。

作者简介: 张金茜,女, 山西长治人,硕士生, 主要研究方向为景观生态学。E-mail: zhangjq2016@1zu.edu.cn

通讯作者:巩杰,E-mail: jgong@1zu.edu.cn 
量进行评估 ${ }^{[20]}$, InVEST 模型作为一个全球性通用模 型已在国内外土壤保持服务的评估中得到较广泛 应用 ${ }^{[2]}$ 。如 $\mathrm{Fu}$ 等 ${ }^{[2]}$ 评估了黄土高原生态系统的土 壤保持功能及其产生的经济价值; 孙文义等 ${ }^{[23]}$ 分析 了近 20 年来黄土高原土壤保持量的空间分布及其 动态变化等。目前涉及景观破碎化对土壤保持服 务的影响研究报道尚少, 相关研究多以生态系统服 务价值为主, 研究方法主要采用相关性分析和经典 回归模型等。如王云等 ${ }^{[2]}$ 开展了西安都市农业景观 破碎化对生态系统服务价值的影响, 其生态系统服 务价值测算采用谢高地等提出的“中国生态系统服 务价值当量表”, 该方法虽简单便捷, 但却忽略了生 态系统服务功能空间分布的不均匀性, 以此得出的 结论稍显欠缺。邹月等 ${ }^{[17]}$ 探讨了西安市景观格局演 变对生态系统服务价值的影响, 其各景观指数与生 态系统服务价值之间的关系仅从数理统计角度开 展研究, 采用了双变量相关性分析, 既未考虑地理 生态现象的空间关系, 研究结果也不能显示两者显 著相关的具体空间范围而略显薄弱。因此, 本文基 于 InVEST 模型定量评估生态系统的土壤保持服 务, 并且运用双变量空间自相关开展景观破碎化对 土壤保持服务的影响研究, 旨在深人了解景观破碎 化与土壤保持服务间的空间关联, 从空间统计角度 确定景观破碎化与土壤保持服务显著相关的区域,
研究结果可为景观格局优化和区域生态系统土壤 保持服务提升等提供参考。

甘肃白龙江流域地处黄土高原和秦巴山地向 青藏高原交错带,地形复杂多变,既是长江上游水 土保持的重要生态区,也是中国四大滑坡和泥石流 灾害高发区之一,环境极度脆弱, 土壤保持服务是 该区重要的生态系统服务类型。因此,本文应用 InVEST 模型开展流域土壤保持服务评估,兼顾流域 不断增强的人类活动及城市化发展背景, 借助 FRAGSTATS、GS+和 ArcGIS 软件开展景观破碎化 程度分析,探讨景观破碎化与土壤保持服务之间的 关联关系,可为甘肃白龙江流域的可持续发展提供 科学依据和决策参考。

\section{2 研究区概况与数据}

\section{1 研究区概况}

甘肃白龙江流域 $\left(32^{\circ} 36^{\prime} \mathrm{N}-34^{\circ} 24^{\prime} \mathrm{N}, 103^{\circ} 00^{\prime} \mathrm{E}-\right.$ $\left.105^{\circ} 30^{\prime} \mathrm{E}\right)$ 位于甘肃省东南部, 是中国滑坡和泥石流 灾害高发区之一, 流域面积约 1.84 万 $\mathrm{km}^{2}$ (图 1)。流 域内气候类型复杂, 上游属高山温带大陆性气候, 中游呈现出干热河谷气候的特点, 气温较高,下游 属亚热带北缘温暖气候, 年均气温 $6 \sim 15^{\circ} \mathrm{C}$, 年均降 水量 400 850mm, 地势西北高东南低, 海拔 573 $4866 \mathrm{~m}$, 差异较大。土壤类型主要有棕壤、暗棕壤、 淋溶褐土、褐土性土、红粘土、暗棕壤性土、石灰性
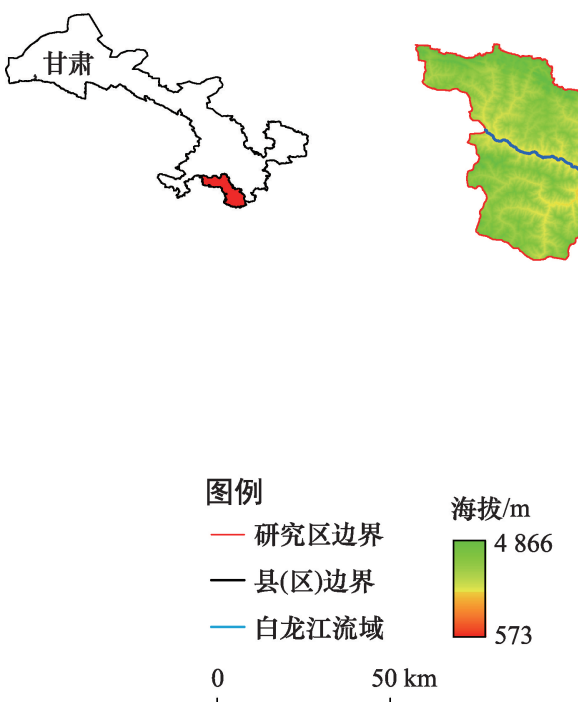

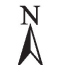
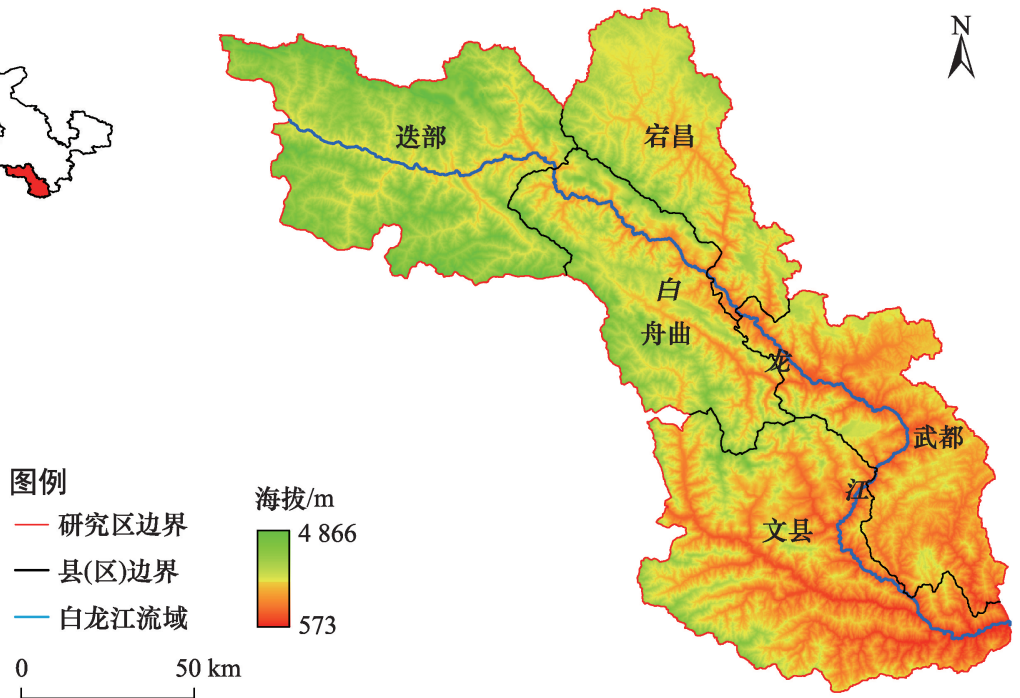

图 1 研究区地理位置

Figure 1 Location of the study area 
褐土、高山草甸土、山地草原草甸土、水稻土、浅黑 钙土、高山寒漠土等; 植被类型主要有温带落叶阔 叶林、常绿阔叶林、温带山地针叶林、高寒山地针叶 林等; 土地利用类型以林地、草地和耕地为主, 林地 主要分布在迭部县大部分区域、文县南部以及武都 东南部山区等区域,以森林自然保护区和林业管护区 最为密集, 草地分布较为广泛和分散, 多为山地草地 和高山草甸, 耕地集中分布在宕昌县、舟曲-武都文县段白龙江两岸河谷地带及其以北区域(图 2)。 流域主要包括迭部县、舟曲县、文县、宕昌县和武都 大部分地区, 辖属 116 个乡镇, 属甘肃省“十二五”农 村扶贫重点区域。区域内农业种植以粮食为主, 兼 种油料作物、蔬菜和药材等; 森林和矿产资源丰富, 旅游业也逐渐发展成为流域的特色。

\section{2 数据来源}

甘肃白龙江流域景观类型图的数据源来自美 国地质勘探局 ${ }^{[25]}$ 的 Landsat TM/ETM+遥感数据, 条 带号/行编号为 129/37、130/37、130/36 和 131/36, 时 间是 1990 年、 2002 年和 2014 年, 空间分辨率为 $30 \mathrm{~m}$, 时相为 7-8 月。根据 LUCC 分类标准 ${ }^{[26]}$ 和甘 肃白龙江流域实际情况, 将土地利用类型分为耕 地、林地、草地、水域、建筑用地和未利用土地共 6 类, 经实地验证与比对, 数据解译整体精度达 $84 \%$ 以上, 满足本研究要求。DEM数据下载于地理数据 云平台 ${ }^{[27]}$, 空间分辨率为 $30 \mathrm{~m}$ 。气象数据源自中国 气象科学数据共享服务网 ${ }^{[28]}$ 和甘肃白龙江流域各县 区气象局, 主要包括研究区及其周边 17 个气象站点
1990-2014年的逐月降水量数据。

\section{3 研究方法与模型}

\section{1 景观格局指数}

基于FRAGSTATS 软件,参考相关文献 ${ }^{[29-33]}$ 并考 虑流域实际情况,选取下列景观格局指数: 边缘密 度 $(\mathrm{ED})$ 、曼延度 $(\mathrm{CONTAG}) 、$ 香农多样性 $(\mathrm{SHDI}) 、$ 分离度 (DIVISION)、聚合度 $(\mathrm{AI})$ 和香农均匀度 (SHEI), 以描述甘肃白龙江流域景观破碎化的整 体特征, 各景观指数计算公式和生态学意义参见 文献 ${ }^{[5,34]}$ 。

为了深人分析甘肃白龙江流域 1990年、2002年 和 2014 年 3 个时期景观格局指数的空间变化特征, 采用网格分析法研究各景观格局指数的区域差 异。参考前人研究 ${ }^{[35-37]}$ 与流域范围大小, 本文以 $10 \mathrm{~km} \times 10 \mathrm{~km}$ 网格作为特征尺度, 将流域共划分为 186 个网格,然后运用FRAGSTATS 软件计算不同时 期各网格的景观格局指数, 并基于 GS+10 和 ArcGIS10.3 地统计模块对各景观格局指数进行普通克 里格插值,得到不同时期甘肃白龙江流域各景观指 数的空间分布图。受篇幅限制, 并考虑景观指数间 相关性的强弱, 本文主要分析 ED、CONTAG 和 SHDI 3 个景观格局指数 1990 年、2002 年和 2014 年 空间分异以表征流域景观破碎程度的变化情况。

\section{2 土壤保持服务定量评估}

土壤保持服务的定量评估基于 InVEST 模型, 其中土壤保持模块认为生态系统土壤保持量由侵 蚀减少量和泥沙持留量两部分组成 ${ }^{[38-41]}$ 。前者反映

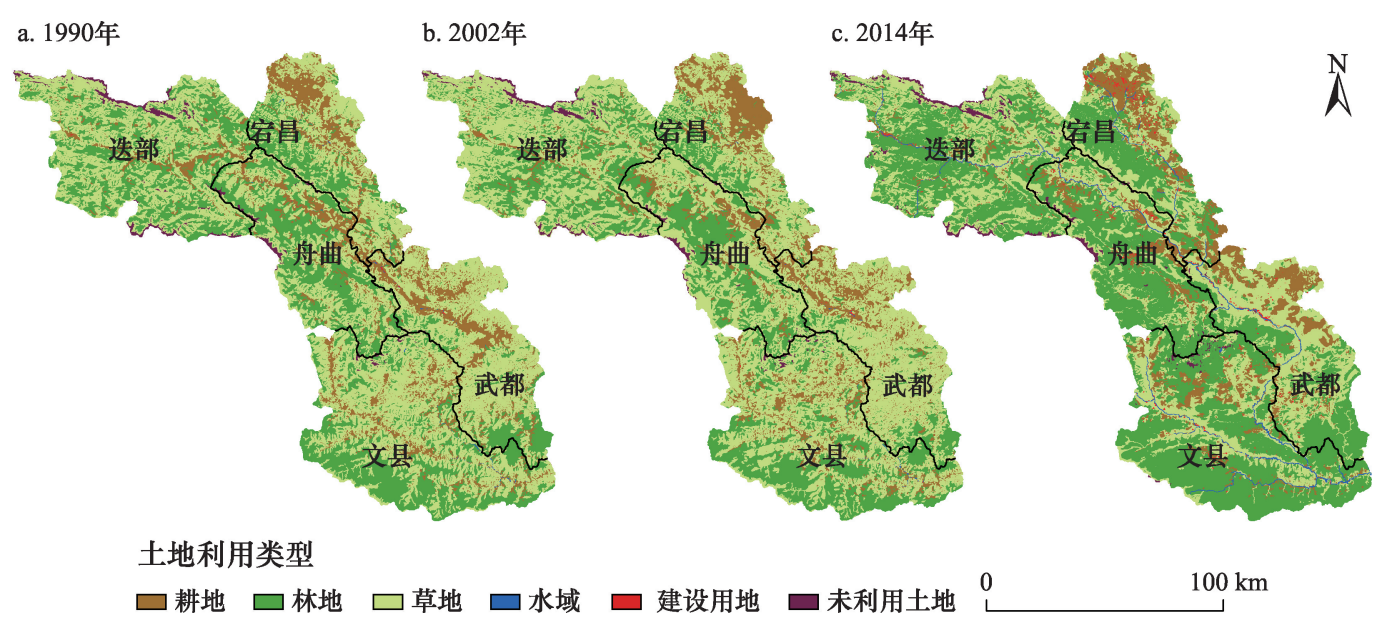

图 2 研究区土地利用类型分布

Figure 2 Land use of the study area 
各地块对自身潜在侵蚀的减少, 以潜在侵蚀与实际 侵蚀的差值表示 ${ }^{[42]}$; 后者是表示某栅格地块拦截上 坡泥沙或其他沉积物的能力, 以来沙量与泥沙持留 效率的乘积表示 ${ }^{[41]}$ 。该模块的特点在于充分考虑了 地块截留上游沉积物的能力。模型具体计算如下:

$$
\begin{aligned}
& \operatorname{SEDRET}_{x}=P K L S_{x}-U S L E_{x}+S E D R_{x} \\
& P K L S_{x}=R_{x} \cdot K_{x} \cdot L S_{x} \\
& U S L E_{x}=R_{x} \cdot K_{x} \cdot L S_{x} \cdot C_{x} \cdot P_{x} \\
& S E D R_{x}=S E_{x} \sum_{y=1}^{x-1} U S L E_{y} \prod_{z=y+1}^{x-1}\left(1-S E_{z}\right)
\end{aligned}
$$

式中 $S E D R E T_{x}$ 和 $S E D R_{x}$ 分别为栅格 $x$ 的土壤保持量 和泥沙持留量; $S E_{x}$ 和 $S E_{z}$ 分别为栅格 $x$ 及其上坡栅 格 $z$ 的泥沙持留效率; $P K L S_{x}$ 为基于地貌和气候条件 的栅格 $x$ 潜在土壤流失量; $U S L E_{x}$ 和 $U S L E_{y}$ 分别为栅 格 $x$ 及其上坡栅格 $y$ 的实际侵蚀量, 即植被覆盖和水 土保持措施下的土壤侵蚀量; $R_{x} 、 K_{x} 、 L S_{x} 、 C_{x}$ 和 $P_{x}$ 分 别为栅格 $x$ 的降雨侵蚀力因子、土壤可蚀性因子、地 形因子、植被覆盖因子和水土保持措施因子。各因 子的计算过程参见文献 ${ }^{[33]}$ 。

\section{3 空间自相关}

\subsection{1 空间权重矩阵构建}

定义空间权重矩阵是空间自相关分析的前提, 即在怎样的空间尺度准则下分析区域之间的关 系 ${ }^{[4]}$ 。本文景观破碎化与土壤保持服务研究均基于 $10 \mathrm{~km} \times 10 \mathrm{~km}$ 的网格单元, 并借助 GeoDA 平台选取 Rook 邻接准则构建空间权重矩阵 $\boldsymbol{W}$ 以表征网格间 的空间关系,其形式如下:

$$
\boldsymbol{W}=\left[\begin{array}{cccc}
w_{11} & w_{12} & \cdots & w_{1 n} \\
w_{21} & w_{22} & \cdots & w_{2 n} \\
\vdots & & & \vdots \\
w_{n 1} & w_{n 2} & \cdots & w_{n n}
\end{array}\right]
$$

式中 $n$ 表示空间单元个数; $w_{i j}$ 表示区域 $i$ 与 $j$ 的邻居 关系 ${ }^{[45]}$ 。本文以 186 个网格单元构建基于空间邻接 关系的权重矩阵, 这里邻接的含义是具有公共边 界,规则如下:

$$
w_{i j}= \begin{cases}1 & \text { 当区域 } i \text { 和 } j \text { 相邻接 } \\ 0 & \text { 其他 }\end{cases}
$$

3.3.2 全局空间自相关

Moran's I 指数反映空间邻接或空间邻近区域 单元属性值的相似程度, 本研究通过 GeoDA 分析流 域各网格单元土壤保持量与景观格局指数之间的 空间关联性,公式如下 ${ }^{[46]}$ :

$$
\begin{aligned}
& I=\frac{n \sum_{i=1}^{n} \sum_{j=1}^{n} w_{i j}\left(x_{i}-\bar{x}\right)\left(x_{j}-\bar{x}\right)}{\sum_{i=1}^{n} \sum_{j=1}^{n} w_{i j} \sum_{i=1}^{n}\left(x_{i}-\bar{x}\right)^{2}} \\
& =\frac{\sum_{i=1}^{n} \sum_{j=1}^{n} w_{i j}\left(x_{i}-\bar{x}\right)\left(x_{j}-\bar{x}\right)}{S^{2} \sum_{i=1}^{n} \sum_{j=1}^{n} w_{i j}} \\
& S^{2}=\frac{1}{n} \sum_{i=1}^{n}\left(x_{i}-\bar{x}\right)^{2} \\
& \bar{x}=\frac{1}{n} \sum_{i=1}^{n} x_{i}
\end{aligned}
$$

式中 $I$ 为 Moran's I 指数; $n$ 为空间单元个数; $x_{i}$ 和 $x_{j}$ 分别为区域 $i$ 和 $j$ 的观测值; $w_{i j}$ 为区域 $i$ 和 $j$ 的空间邻 接关系; $S^{2}$ 表示观测值的方差。 $I$ 的取值一般在 $[-1$, 1]之间,小于 0 表示在空间呈负相关,大于 0 表示在 空间呈正相关,等于 0 表示不相关,随机分布。

\subsection{3 局部空间自相关}

局部 Moran's I指数可表征一个区域与邻近区 域属性值的相关程度, 本研究通过 GeoDA 分析流域 网格单元土壤保持量与邻近网格单元景观格局指 数的空间相关程度, 公式如下 ${ }^{[47]}$ :

$$
I_{i}=\frac{\left(x_{i}-\bar{x}\right)}{S^{2}} \sum_{j} w_{i j}\left(x_{j}-\bar{x}\right)
$$

\section{4 结果分析}

\section{1 流域景观破碎化的时空分布特征}

甘肃白龙江流域景观格局指数的变化规律表 明，1990-2002 年流域景观的破碎化程度有所增 加, 2002-2014年景观破碎化程度降低(表 1)。由

表 $11990-2014$ 年甘肃白龙江流域景观水平的各景观格局指数

Table 1 Landscape pattern indices in the Bailongjiang Watershed in Gansu Province from 1990 to 2014

\begin{tabular}{ccccccc}
\hline & $\mathrm{ED} /\left(\mathrm{m} / \mathrm{km}^{2}\right)$ & CONTAG $/ \%$ & SHDI & DIVISION $/ \%$ & AI $/ \%$ & SHEI \\
\hline 1990年 & 28.42 & 62.16 & 1.15 & 0.98 & 95.72 & 0.64 \\
2002年 & 29.25 & 61.00 & 1.19 & 0.97 & 95.60 & 0.66 \\
2014年 & 22.36 & 63.83 & 1.12 & 0.95 & 96.63 & 0.62 \\
\hline
\end{tabular}


表 1 可以看出, 1990-2014年流域景观的边缘密度 (ED)、香农多样性 (SHDI) 和香农均匀度 (SHEI) 呈 现先增后减的变化趋势, 表征流域景观在边缘形状 上由复杂向简单发展, 在景观类型组成上由多样向 单一发展,在景观各类型的均匀程度上由高向低发 展; 景观蔓延度 (CONTAG) 呈现先减后增的变化趋 势, 表明流域景观中不同斑块类型的团聚程度由弱 到强, CONTAG 越高, 说明景观中有连通性较高的 优势斑块存在, 连接性较好, 反之则存在较多的小 斑块, 要素格局相对密切, 破碎化程度较高; 聚合度 $(\mathrm{AI})$ 与蔓延度 $(\mathrm{CONTAG})$ 的变化趋势相同, $\mathrm{AI}$ 可说 明每种景观类型斑块间的连通性, 值越小, 景观越 离散; 景观分离度(DIVISION) 呈微弱下降态势。综
合分析表明, 1990-2014年流域景观的破碎化程度 先增加后降低。

甘肃白龙江流域边缘密度(ED)空间分布情况 如图 3。1990年流域ED高值区主要分布在武都、文 县东南及东部、宕昌中部, 低值区主要是文县南部、 舟曲中部、迭部南部(图 3a); 2002 年武都及文县东 南 ED 显著提高(图 3b);2014年ED高值区大范围减 少,尤以武都和文县东部最为显著 (图 3c)。总体来 说, 1990-2014年,ED剧烈变化区主要是流域东南 部,如武都区和文县,其余各县变化相对较小。

甘肃白龙江流域蔓延度 (CONTAG) 空间分布 情况如图 4。1990 年流域 CONTAG 高值区与低值 区在空间上交错分布,低值区主要是武都大部、文

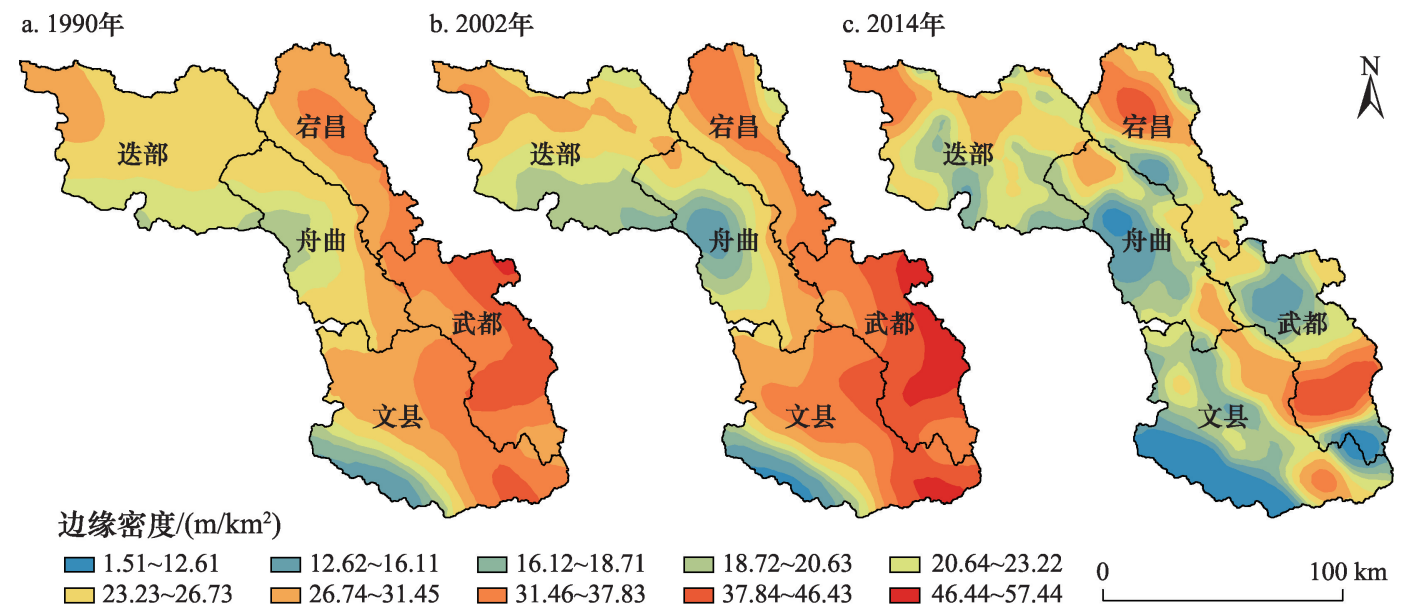

图 3 甘肃白龙江流域边缘密度 (ED) 时空变化

Figure 3 Spatiotemporal variation of edge density index(ED) in the Bailongjiang Watershed in Gansu Province

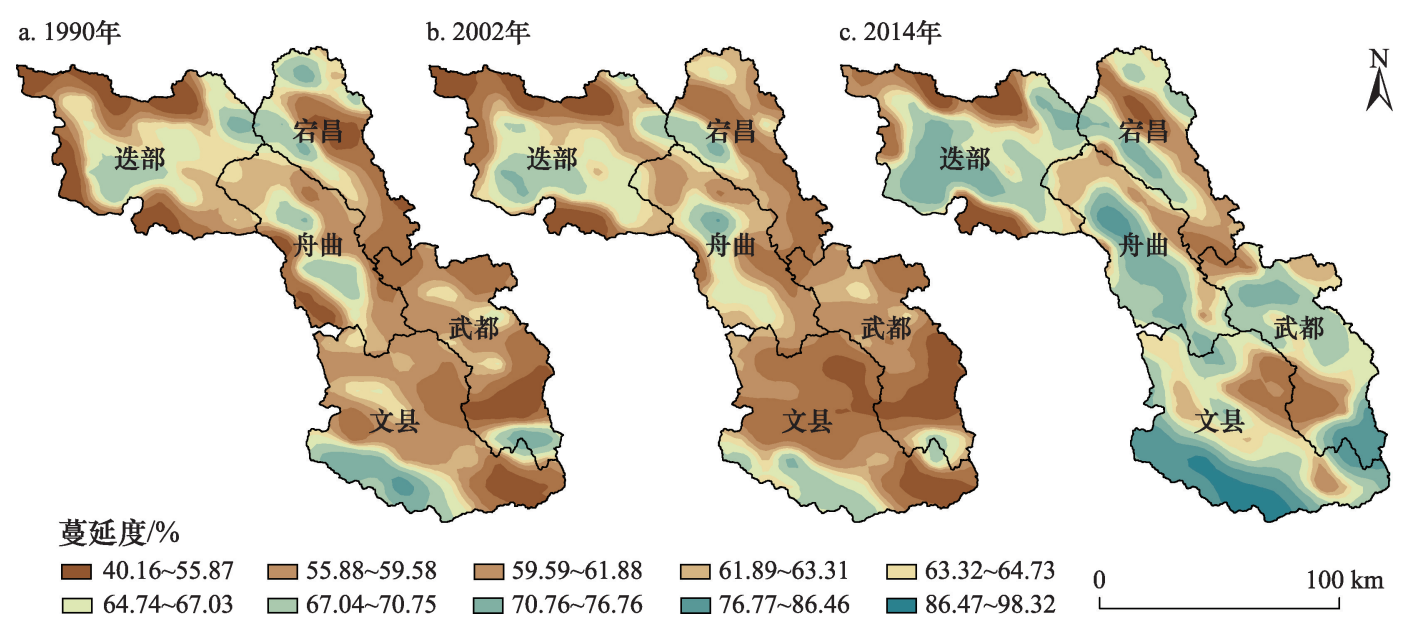

图 4 甘肃白龙江流域蔓延度 (CONTAG) 时空变化

Figure 4 Spatiotemporal variation of the contagion index (CONTAG) in the Bailongjiang Watershed in Gansu Province 
县东部和宕昌中部及南部 (图 4a)；2002 年流域 CONTAG 低值区以武都和文县东部为中心扩展开 来, 分布面积显著增加, 其余各县变化不显著 (图 $4 b$ ) ; 至 2014 年 CONTAG 低值区大范围缩减, 尤以 武都和文县显著(图 4c)。总体来说，1990-2014 年, CONTAG 在各县 (区) 均有较明显的变化, 但流 域东南部的变化最为剧烈和复杂。

甘肃白龙江流域香农多样性 (SHDI) 空间分布 情况如图 5。1990 年流域 SHDI 高值区主要分布在 流域中部且呈现条状分布的空间格局特征, 分布面 积较少, 低值区主要是文县南部及迭部西部(图 5a）; 2002 年 SHDI 高值区面积显著增加, 集中在文 县大部及宕昌-舟曲-武都交界处 (图 5b);2014年 SHDI 高值区与 2002 年相比显著减少 (图 5c)。总体 来说, 1990-2014 年, 流域绝大部分 SHDI 发生变 化,尤以文县变化剧烈。

综合分析景观指数 ED、CONTAG、SHDI 空间 分布规律表明, 1990-2014年流域东南部的景观破 碎化先强后弱, 其变化最为剧烈和复杂, 以文县和 武都区为主。1990-2002 年流域东南部景观破碎 化程度显著增强, 可能的主要原因有: 流域东南部 主要是农耕区, 人口密度较大, 人类活动对景观的 干扰相对较强; 随着时间的推移, 流域人口逐渐增 多, 耕地需求量不断上涨, 而流域东南部的山前平 原、低丘及河谷带更易开发转变为耕地; 人们开剭 行为、过度放牧和樵采以及道路网络建设等加剧了
流域景观破碎化。2002-2014 年流域东南部景观 破碎化程度明显减弱,可能原因是: 流域农业生产 活动趋于有序和规模化; 山间川地或低坡地生产力 的提高以及河川地农业生态系统 “造血”能力的增 强使农作物增产增收; 退耕还林(还草)政策使得陡 坡耕地大面积退耕转变为林草地; 新农村建设使人 类居住用地高密度集中起来, 这在一定程度上减弱 了流域的景观破碎化程度。

\section{2 流域土壤保持服务的时空分布特征}

1990-2014 年甘肃白龙江流域土壤保持量的 最大值和平均值均表现为先减小后增大的趋势, 表 明流域内土壤保持功能呈现先降后升的变化趋势 （图 6）。从空间分布来看,流域土壤保持空间格局 具有明显的分异性,其高值区域主要分布在流域东 南部以及迭部中西部,这些区域多属于石质山区或 人类活动较少的自然保护区。低值区域集中分布 在人类活动相对频繁、工农业相对发达的迭部北 部、舟曲-武都-文县段白龙江河谷沿岸地带(图6)。 与 1990 年相比, 2014 年土壤保持量高值区域增加, 其增加区域主要分布在迭部中部及武都东南部;土 壤保持量低值区域变化不大。

\section{3 流域景观破碎化对土壤保持服务的影响}

4.3.1 流域景观破碎化与土壤保持服务的相关关系

基于 SPSS 软件, 以流域内各网格的土壤保持 量和景观格局指数为基础数据作相关性分析, 结果

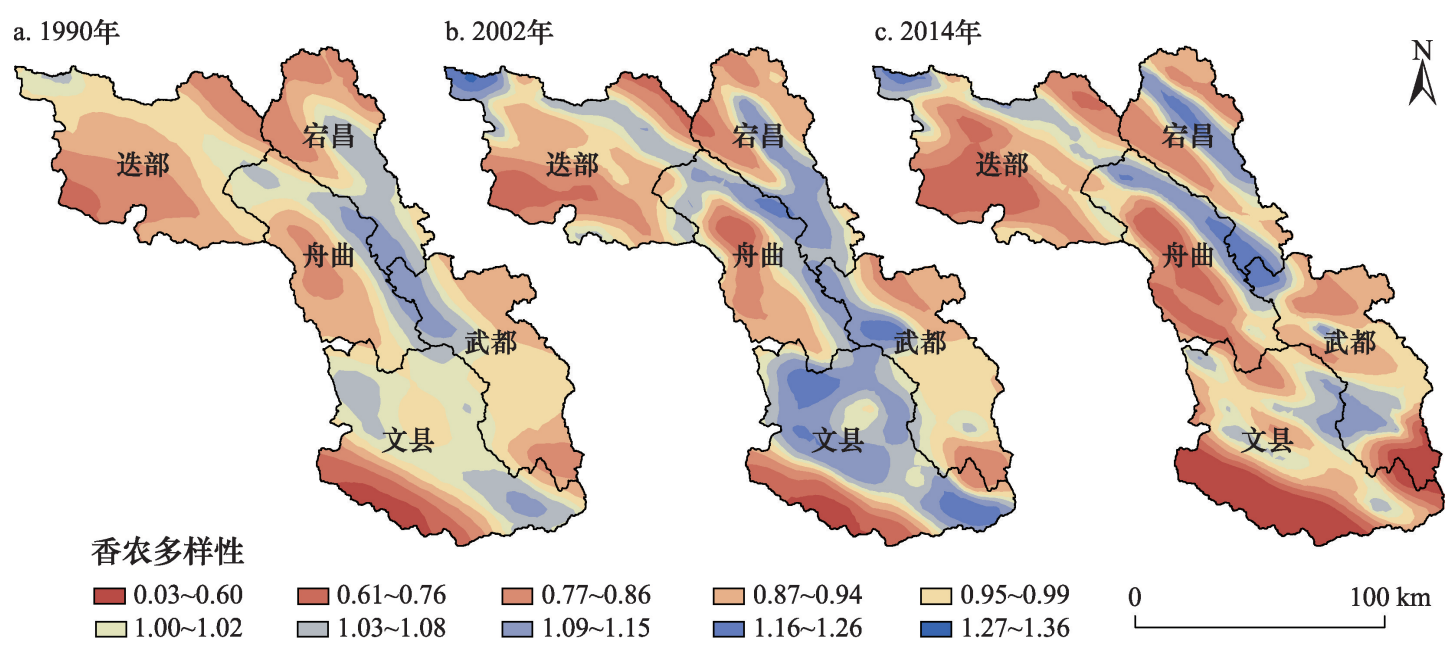

图 5 甘肃白龙江流域香农多样性 (SHDI) 时空变化

Figure 5 Spatiotemporal variation of Shannon-Wiener index (SHDI) in the Bailongiiang Watershed in Gansu Province 


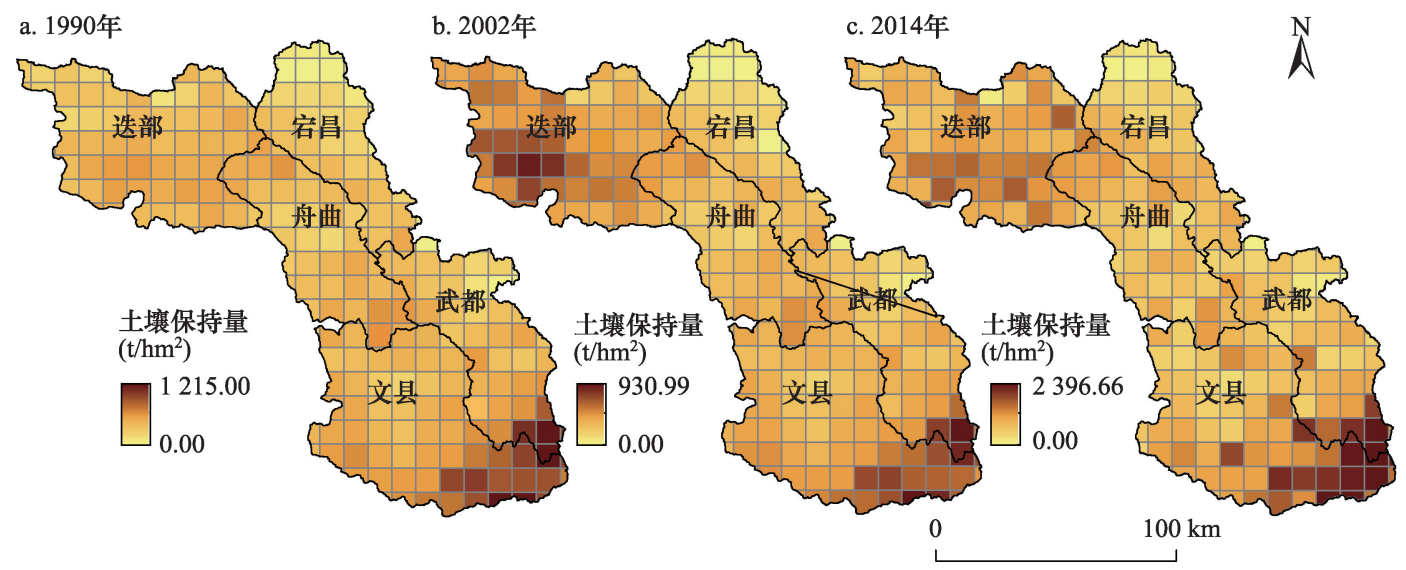

图 6 甘肃白龙江流域土壤保持服务时空变化

Figure 6 Spatiotemporal variation of soil conservation service in the Bailongjiang Watershed in Gansu Province

表明 2002 年流域土壤保持与部分景观指数 (ED、 CONTAG、SHDI、AI、SHEI) 呈显著相关关系, 至 2014 年与 6 个景观指数均呈现显著相关关系, 且相 关关系更为显著,表征 2014年流域景观破碎化对土 壤保持服务有一定负向影响 (表 2)。具体来看, 1990 年土壤保持与景观格局指数边缘密度 (ED)、 香农多样性 (SHDI)、分离度 (DIVISION) 和聚合度 (AI) 的相关系数几乎为 0 (无相关关系); 与 1990 年 相比, 2002 年土壤保持与景观格局指数 ED、CONTAG、SHDI、AI、SHEI 的相关系数增加并呈现显著 相关; 2014 年土壤保持与景观格局指数 ED、SHDI、 DIVISION、SHEI 的相关系数分别为 $-0.188 、-0.367$ 、 $-0.268 、-0.368$ (显著负相关), 表征流域内土壤保持 服务较高的区域, 其景观类型组成及边缘形状较单 一和规整, 景观的分割与均匀程度较弱; 而与景观 格局指数 CONTAG、AI 的相关系数分别是 0.358 、 0.181 (显著正相关), 表征流域内土壤保持服务较高 的区域, 其景观相对聚合, 连接性较好, 具有连通性 较高的优势斑块存在, 破碎化程度较低。综合分析 发现, 1990-2014年间, 流域土壤保持服务与景观
格局指数 ED、CONTAG、SHDI、AI 和 SHEI 的相关 性一直在增加, 至 2014 年与全部景观格局指数均具 有显著关系, 即景观破碎化对土壤保持服务的影响 逐渐增强。

4.3.2 流域景观破碎化与土壤保持服务的全局空间 自相关

空间依赖性和异质性是土壤保持及景观破碎 化等地理生态现象的内在属性, 仅借助 SPSS 从数 理统计角度分析流域土壤保持量与各景观格局指 数的相关关系略显薄弱, 因此在考虑空间关系前提 下开展两者间的空间关联性分析成为必要。本文 通过 GeoDA 软件对 1990年、2002年、2014年的流域 土壤保持量与各景观指数进行全局空间自相关分 析, 结果表明 2002 年流域土壤保持与部分景观指数 （ED、SHDI、AI）呈空间相关关系, 至 2014 年与 6 个 景观指数均呈空间相关性,且空间相关关系更为显 著(表 3)。表 3 显示, 1990年流域土壤保持与景观 指数 ED、CONTAG、SHDI、DIVISION、AI、SHEI 的 Moran's I 分别为 $-0.006 、 0.068 、-0.056 、-0.048$ 、 $0.006 、-0.078$ (接近于 0$)$, 表征流域土壤保持与景观

表 $21990-2014$ 年甘肃白龙江流域各景观格局指数与土壤保持服务的相关关系

Table 2 Correlation between landscape pattern indices and soil conservation service in the Bailongjiang Watershed in Gansu Province from 1990 to 2014

\begin{tabular}{ccccccc}
\hline & ED & CONTAG & SHDI & DIVISION & AI & SHEI \\
\hline 1990年土壤保持量 & -0.043 & $0.167^{*}$ & -0.078 & -0.096 & 0.045 & $-0.173^{*}$ \\
2002年土壤保持量 & $-0.148^{*}$ & $0.199^{* *}$ & $-0.171^{*}$ & -0.069 & $0.146^{*}$ & $-0.184^{*}$ \\
2014年土壤保持量 & $-0.188^{*}$ & $0.358^{* *}$ & $-0.367^{* *}$ & $-0.268^{* *}$ & $0.181^{*}$ & $-0.368^{* *}$ \\
\hline
\end{tabular}

注: ***分别表示在 $0.05 、 0.01$ 水平水平 $($ 双侧) 上显著相关。 
表 $31990-2014$ 年甘肃白龙江流域各景观格局指数与土壤保持服务的 Moran’s I

Table 3 Moran's I between landscape pattern indices and soil conservation service in the Bailongiiang Watershed in Gansu Province from 1990 to 2014

\begin{tabular}{ccccccc}
\hline & ED & CONTAG & SHDI & DIVISION & AI & SHEI \\
\hline 1990年土壤保持量 & -0.006 & 0.068 & -0.056 & -0.048 & 0.006 & -0.078 \\
2002年土壤保持量 & -0.119 & 0.097 & -0.134 & -0.025 & 0.116 & -0.080 \\
2014年土壤保持量 & -0.155 & 0.243 & -0.291 & -0.175 & 0.149 & -0.250 \\
\hline
\end{tabular}

破碎化在空间分布上并无相关关系。相比 1990年， 2002 年其 Moran' s I 的绝对值均有一定程度增加 (除DIVISION外), 土壤保持与 ED、SHDI 呈空间负 相关,与 AI呈空间正相关,即土壤保持高值区域的 景观在边缘形状和类型组成上相对简单和单一且 聚合度高。2014年流域土壤保持与景观指数 ED、 CONTAG、SHDI 、DIVISION、AI、SHEI 的 Moran’s I 绝对值明显增加, 表明土壤保持高值区域的景观在 边缘形状、类型组成、团聚程度以及均匀程度上具 有较简单、单一、连通性好、均匀度低、破碎化程度 低的特征。综合分析表明, 1990-2014年间,流域
土壤保持服务与景观破碎化的空间相关关系由无 向有发展。

4.3.3 流域景观破碎化与土壤保持服务的局部空间 自相关

2014 年甘肃白龙江流域土壤保持与景观破碎 化的空间关联性最为显著,因此以 2014年为研究年 份,运用GeoDA 软件深人分析流域土壤保持与景观 破碎化空间相关的具体范围,并生成双变量局部空 间自相关的聚集图,不同颜色标识不同的空间自相 关类别 (图 7)。由图 7 可以看出, 在 $95 \%$ 的置信度 下,土壤保持与景观指数 ED 的高低聚集区集中分
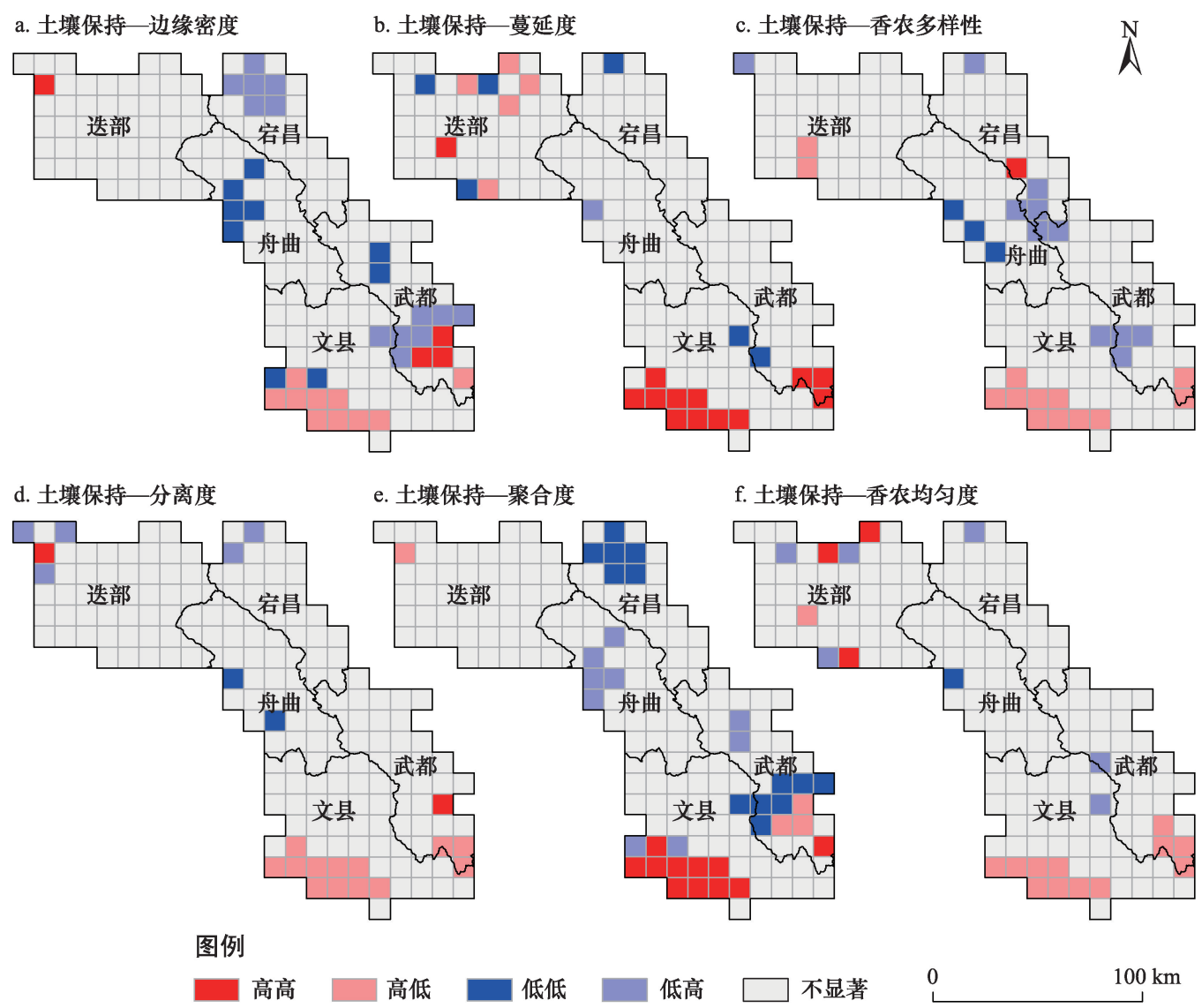

图 72014 年甘肃白龙江流域各景观格局指数与土壤保持服务的局部空间自相关聚集分布

Figure 7 Local spatial autocorrelation cluster map of landscape pattern indices and soil conservation service in the Bailongjiang Watershed in Gansu Province in 2014 
布在文县南部, 表征该区土壤保持高值和边缘密度 低值形成集聚现象, 即土壤保持服务较高区域的景 观在边缘形状上相对规整; 低高聚集区主要分布在 宕昌北部和武都中南部, 说明该区土壤保持服务较 低的同时边缘密度较高, 表明景观边缘形状相对复 杂的区域土壤保持功能较弱。土壤保持与景观指 数 SHDI 的空间集聚特征和 ED 有相似之处, 高低聚 集区也主要分布在文县南部, 只是低高聚集区的分 布情况有所不同,低高聚集区集中分布在流域中部 (宕昌-舟曲-武都交汇处)和武都中南少部分区域, 表征该区土壤保持服务较低的同时区域景观在组 成类型上较多样化, 空间相关关系显著。土壤保持 与景观指数 CONTAG 和 AI 的高高聚集区均主要分 布在文县南部, 说明该区土壤保持服务较高区域的 景观有连通性较高的优势斑块存在, 连接性及聚合 度较高, 破碎程度较低, 但低低聚集区的空间分布 特征却不相同, 土壤保持与景观指数 $\mathrm{AI}$ 的低低聚集 区分布集中, 主要是在宕昌北部和武都中南部, 而 与景观指数 CONTAG 的低低聚集区则分布相对分 散。土壤保持与景观指数 DIVISION 和 SHEI 的高 低聚集区均集中于文县南部及武都最南端, 说明该 区景观分割和均匀程度较低的同时土壤保持服务 保持较高水平, 低高聚集区空间分布相对分散。综 合分析双变量局部空间自相关结果可以表明,流域 土壤保持与景观破碎化的显著空间负相关关系主 要表现在宕昌北部、武都中南部及最南端、文县南 部和宕昌-舟曲-武都交汇处,换言之,这些区域的 景观破碎化程度对土壤保持服务产生显著负向影响。

\section{5 讨论与结论}

\section{1 讨论}

(1) 景观破碎化通过影响生态系统组份、结构 与生物化学过程进而影响生态系统服务, 这是一个 非常复杂的相互作用过程, 会导致生态系统服务增 加或减少 ${ }^{[48-50]}$ 。比如本文发现 1990-2014年间, 研 究区景观破碎化对土壤保持服务的负向影响逐渐 增强, 但这只是复杂作用过程的结果, 目前还难以 解释其内在机制。因此, 明晰景观破碎化对生态系 统的作用关系与机制, 并在此基础上探讨其对生态 系统服务的影响是进一步研究方向。

(2) 尺度问题是景观生态学的核心问题 ${ }^{[1]}$, 景观
破碎化与土壤保持服务的相关关系研究需要关注 尺度对生态过程和机制的影响。尺度选择过大,往 往导致大量细节被忽略; 尺度选择过小, 就会陷人 局部而忽略总体规律,因此选择适宜的研究尺度显 得极为重要。本文仅以 $10 \mathrm{~km} \times 10 \mathrm{~km}$ 为特征尺度探 讨了景观破碎化对土壤保持服务的影响,后期将深 人研究不同空间尺度或连续空间尺度对两者关系 的影响。同时,本文采用的空间权重矩阵只是基于 邻接准则简单构建,若是基于其它邻接准则或距离 确立更为复杂的空间权重矩阵,会对景观破碎化与 土壤保持服务的相关关系是否产生影响或产生多 大影响,这也是以后探讨的重点。

\section{2 结论}

（1）1990－2014年甘肃白龙江流域景观破碎化 程度先增加后降低,以流域东南部的变化最为剧烈 和复杂,主要是文县和武都区 ; 流域内土壤保持服 务呈先降后升的变化趋势。

(2) 从数理统计和空间统计两个角度揭示了 1990-2014年间,甘肃白龙江流域土壤保持服务与 景观破碎化的空间负相关关系从无向有发展,且两 者间的空间关联性逐渐增强。2014年宕昌北部、武 都中南部及最南端、文县南部和宕昌-舟曲-武都交 汇处的景观破碎化程度对该区土壤保持服务产生 显著负影响,要实现上述区域土壤保持服务提升的 生态管理目标,降低该区域的景观破碎化程度是有 效途径之一。

\section{参考文献(References):}

[1] 吴健生, 王政, 张理卿, 等. 景观格局变化驱动力研究进展 [J]. 地 理科学进展, 2012, 31(12): 1739-1746. [Wu J S, Wang Z, Zhang L Q, et al. Research progresses on driving forces of the changes of landscape pattern [J]. Progress in Geography, 2012, 31(12): 17391746. ]

[2] Lambin E F, Geist H. Land Use and Land Cover Change: Local Processes and Global Impacts[M]. Berlin: Springer, 2006.

[3] 姜朋辉. 黑河中游湿地景观破碎化过程及其驱动机制分析[D]. 兰州: 西北师范大学, 2013. [Jiang P H. Fragmentation Process of Wetlands Landscape of the Middle Reaches of the Heihe River and Its Driving Forces Analysis[D]. Lanzhou: Northwest Normal University, 2013.]

[4] 王宪礼, 布仁仓, 胡远满, 等. 辽河三角洲湿地的景观破碎化分 
析[J]. 应用生态学报, 1996, 7(3): 299-304. [Wang X L, Bu R C, $\mathrm{Hu}$ Y M, et al. Analysis on landscape fragment of Liaohe delta wetlands[J]. Chinese Journal of Applied Ecology, 1996, 7(3): 299304. ]

[5] 刘红玉, 吕宪国, 张世奎, 等. 三江平原流域湿地景观破碎化过 程研究[J]. 应用生态学报, 2005, 16(2): 289-295. [Liu H Y, Lv X G, Zhang S K, et al. Fragmentation process of wetland landscape in watersheds of Sanjiang Plain, China[J]. Chinese Journal of Applied Ecology, 2005, 16(2): 289-295. ]

[6] 黄青, 王让会, 吴世新. 塔里木河上游景观破碎化的时空动态变 化分析[J]. 干旱区资源与环境, 2007, 21(9): 73-77. [Huang Q, Wang R H, Wu S X. Spatial-temporal dynamic changes of landscape fragmentation in the upper reaches of Tarim River[J]. Journal of Arid Land Resources and Environment, 2007, 21(9): 73-77. ]

[7] 李文杰, 乌铁红, 李晓佳. 内蒙古希拉穆仁草原旅游地景观格局 动态变化[J]. 地理科学, 2013, 33(3): 307-313. [Li W J, Wu T H, Li X J. Dynamic change of landscape pattern in Xilamuren grassland tourist area of Inner Mongolia[J]. Scientia Geographica Sinica, 2013, 33(3): 307-313. ]

[ 8 ] Pereira J, Jordán F. Multi-node selection of patches for protecting habitat connectivity: fragmentation versus reachability[J]. Ecological Indicators, 2017, 81: 192-200.

[9] Langlois L A, Drohan P J, Brittingham M C. Linear infrastructure drives habitat conversion and forest fragmentation associated with Marcellus shale gas development in a forested landscape[J]. Journal of Environmental Management, 2017, 197: 167-176.

[10] 刘红玉, 李兆富, 李晓民. 湿地景观破碎化对东方白鹳栖息地的 影响-以三江平原东北部区域为例[J]. 自然资源学, 2007, 22 (5): 817-823. [Liu H Y, Li Z F, Li X M. Effects of wetland landscape fragmentation on habitats of oriental white storks-a case study on northeastern Sanjiang Plain, China[J]. Journal of Natural Resources, 2007, 22(5): 817-823. ]

[11] Mitchell M G, Suarez-Castro A F, Martinez-Harms M, et al. Reframing landscape fragmentation's effects on ecosystem services [J]. Trends in Ecology \& Evolution, 2015, 30(4): 190-198.

[12] 刘珍环, 王仰麟, 彭建, 等. 深圳市水体景观破碎化动态及其生 态价值变化[J]. 北京大学学报(自然科学版), 2010, 46(2): 286292. [Liu Z H, Wang Y L, Peng J, et al. Urban water landscape fragmentation and the change of ecological values in Shenzhen[J]. Acta Scicentiarum Naturalum Universitis Pekinesis, 2010, 46(2): 286-292. ]

[13] Su S L, Xiao R, Jiang Z L, et al. Characterizing landscape pattern and ecosystem service value changes for urbanization impacts at an eco-regional scale[J]. Applied Geography, 2012, 34(1): 295-305.

[14] Sun C, Wu Z F, Lu Z Q, et al. Quantifying different types of urban growth and the change dynamic in Guangzhou using multi-temporal remote sensing date[J]. International Journal of Applied Earth
Observation and Geoinformation, 2013, 21(1): 409-417.

[15] Daily G C. Natures' services: societal dependence on natural ecosystems[J]. Pacific Conservation Biology, 1997, 6(2): 220-221.

[16] Costanza R, D'Arge R, Groot R D, et al. The value of the world's ecosystem services and natural capital[J]. Nature, 1997, 387: 253260.

[17] 邹月, 周忠学. 西安市景观格局演变对生态系统服务价值的影 响[J]. 应用生态学报, 2017, 28(8): 2629-2639. [Zou Y, Zhou Z $\mathrm{X}$. Impact of landscape pattern change on ecosystem service value of Xi' an City, China[J]. Chinese Journal of Applied Ecology, 2017, 28(8): 2629-2639. ]

[18] Liu H Y, Li Y F, Cao X, et al. The current problems and perspectives of landscape research of wetlands in China[J]. Acta Geographica Sinica, 2009, 64(11): 1394-1401.

[19] 谢高地, 肖玉, 鲁春霞. 生态系统服务研究: 进展、局限和基本范 式[J]. 植物生态学报, 2006, 30(2): 191-199. [Xie G D, Xiao Y, Lu C X. Study on ecosystem services: progress, limitation and basic paradigm[J]. Chinese Journal of Plant Ecology, 2006, 30(2): 191-199. ]

[20] 王鹏涛, 张立伟, 李英杰, 等. 汉江上游生态系统服务权衡与协 同关系时空特征[J]. 地理学报, 2017, 72(11): 2064-2078. [Wang P T, Zhang L W, Li Y J, et al. Spatiotemporal characteristics of the trade-off and synergy relationships among multiple ecosystem services in the Upper Reaches of Hanjiang River Basin[J]. Acta Geographica Sinica, 2017, 72(11): 2064-2078. ]

[21] 王菩, 赵军, 胡秀芳. 基于 InVEST 模型的黑河流域生态系统服 务空间格局分析[J]. 生态学杂志, 2016, 35(10): 2783-2792. [Wang B, Zhao J, Hu X F. Spatial pattern analysis of ecosystem services based on InVEST in Heihe River Basin[J]. Chinese Journal of Ecology, 2016, 35(10): 2783-2792. ]

[22] Fu B J, Liu Y, Lv Y H, et al. Assessing the soil erosion control service of ecosystems change in the Loess Plateau of China[J]. Ecological Complexity, 2011, 8(4): 284-293.

[23] 孙文义, 邵全琴, 刘纪远. 黄土高原不同生态系统水土保持服务 功能评价 [J]. 自然资源学报, 2014, 29(3): 365-376. [Sun W Y, Shao Q Q, Liu J Y. Assessment of soil conservation function of the ecosystem services on the loess plateau [J]. Journal of Natural Resources, 2014, 29(3): 365-376. ]

[24] 王云, 周忠学, 郭钟哲. 都市农业景观破碎化过程对生态系统服 务价值的影响-以西安市为例[J]. 地理研究, 2014, 33(6): 10971105. [Wang Y, Zhou Z X, Guo Z Z. Impact of the urban agricultural landscape fragmentation on ecosystem services: a case study of Xi' an City[J]. Geographical Research, 2014, 33(6): 1097-1105. ]

[25] United States Geological Survey. Remote Land Sensing and Landsat [EB/OL]. (2017-03-10)[2017-10-28]. http: //glovis. usgs. gov.

[26] 刘纪远. 中国资源环境遥感宏观调查与动态研究 $[M]$. 北京: 中 国科学技术出版社, 1996. [Liu J Y. Remote Sensing Macro Sur- 
vey and Dynamic Study of Resources and Environment in China [M]. Beijing: China Science and Technology Press, 1996. ]

[27] 中国科学院. 地理空间数据云[EB/OL]. (2016-10-28)[2017-1028]. http: //www. gscloud. cn. [Chinese Academy of Sciences. Geospatial Data Cloud [EB/OL]. (2016-10-28)[2017-10-28]. http: // www. gscloud. cn. ]

[28] 中国气象局. 中国气象科学数据共享服务网[EB/OL]. (201606-27)[2017-10-28]. http: //cdc. cma. gov. cn. [China Meteorological Administration. China Meteorological Data Sharing Service Network [EB/OL]. (2016-06-27)[2017-10-28]. http://cdc. cma. gov. cn. ]

[29] 汤萃文, 张海风, 陈银萍, 等. 祁连山南坡植被景观格局及其破 碎化 [J]. 生态学杂志, 2009, 28(11): 2305-2310. [Tang C W, Zhang H F, Chen Y P, et al. Vegetation landscape pattern and its fragmentation on southern slope of Qilian Mountain[J]. Chinese Journal of Ecology, 2009, 28(11): 2305-2310. ]

[30] 王艳芳, 沈永明. 盐城国家级自然保护区景观格局变化及其驱 动力[J]. 生态学报, 2012, 32(15): 4844- 4851. [Wang Y F, Shen Y M. Analysis on landscape pattern change and its driving forces of Yancheng National Natural Reserve[J]. Acta Ecologica Sinica, 2012, 32(15): 4844-4851. ]

[31] 胡苏军, 葛小东, 黄超. 科尔沁沙地近水区域景观破碎化时空变 化研究[J]. 干旱区资源与环境, 2012, 26(9): 125-131. [Hu S J, Ge X D, Hang C. Landscape fragmentation around surface water in Horqin Sandy Land-a case study in Naiman Banner[J]. Journal of Arid Land Resources and Environment, 2012, 26(9): 125-131. ]

[32] 付刚, 肖能文, 乔梦萍, 等. 北京市近二十年景观破碎化格局时 空变化分析 [J]. 生态学报, 2017, 37(8): 1-12. [Fu G, Xiao N W, Qiao M P, et al. Spatiotemporal changes of landscape fragmentation patterns in Beijing in the last two decades[J]. Acta Ecologica Sinica, 2017, 37(8): 1-12. ]

[33] 巩杰, 孙朋, 谢余初, 等. 基于移动窗口法的肃州绿洲化与景观 破碎化时空变化[J]. 生态学报, 2015, 35(19): 6470-6480. [Gong J, Sun P, Xie Y C, et al. Spatiotemporal change and landscape fragmentation in Suzhou oasis using the moving window method[J]. Acta Ecologica Sinica, 2015, 35(19): 6470-6480. ]

[34] 邬建国. 景观生态学-格局、过程、尺度与等级(第二版)[M]. 北 京: 高等教育出版社, 2007. [Wu J G. Landscape Ecology-Pattern, Process, Scale and Hierarchy(2nd)[M]. Beijing: Higher Education Press, 2007. ]

[35] 张玲玲, 赵永华, 殷莎, 等. 基于移动窗口法的岷江干旱河谷景 观格局梯度分析 [J]. 生态学报, 2014, 34(12): 3276-3284. [Zhang L L, Zhao Y H, Yin S, et al. Gradient analysis of dry valley of Minjiang River landscape pattern, based on moving window method[J]. Acta Ecologica Sinica, 2014, 34(12): 3276-3284. ]

[36] 李栋科, 丁圣彦, 梁国付, 等. 基于移动窗口法的豫西山地丘陵 地区景观异质性分析[J]. 生态学报, 2014, 34(12): 3414-3424.
[Li D K, Ding S Y, Liang G F, et al. Landscape heterogeneity of mountainous and hilly area in the western Henan Province based on moving window method[J]. Acta Ecologica Sinica, 2014, 34(12): 3414-3424. ]

[37] 刘吉平, 董春月, 盛连喜, 等. 1955 2010 年小三江平原沼泽湿 地景观格局变化及其对人为干扰的响应 [J]. 地理科学, 2016, 36(6): 879-887. [Liu J P, Dong C Y, Sheng L X, et al. Landscape pattern change of marsh and its response to human disturbance in the Small Sanjiang Plain, 1955-2010[J]. Scientia Geographica Sinica, 2016, 36(6): 879-887. ]

[38] Tallis H T, Ricketts T, Nelson E, et al. InVEST2. 5. 4 User's Guide[M]. Stanford: The Natural Capital Project, 2013.

[39] 李婷, 刘康, 胡胜, 等. 基于 InVEST 模型的秦岭山地土壤流失及 土壤保持生态效益评价[J]. 长江流域资源与环境, 2014, 23(9): 1242-1250. [Li T, Liu K, Hu S, et al. Soil erosion and ecological benefits evaluation of Qinling Mountains based on the InVEST model[J]. Resources and Environment in the Yangtze Basin, 2014, 23(9): 1242-1250. ]

[40] 饶恩明, 肖炏, 欧阳志云, 等. 海南岛生态系统土壤保持功能空 间特征及影响因素[J]. 生态学报, 2013, 33(3): 746-755. [Rao E M, Xiao Y, Ouyang Z Y, et al. Spatial characteristics of soil conservation service and its impact factors in Hainan Island[J]. Acta Ecologica Sinica, 2013, 33(3): 746-755. ]

[41] 胡胜, 曹明明, 张天琪, 等. 基于InVEST 模型的小流域沉积物保 留生态效益评估-以陕西省营盘山库区为例 [J]. 资源科学, 2015, 37(1): 76-84. [Hu S, Cao M M, Zhang T Q, et al. Ecological benefits evaluation of small watershed sediment retention based on the In VEST model[J]. Resources Science, 2015, 37(1): 76-84. ]

[42] Rife T L. Modeling the Value of Ecosystem Services: Application to Soil Loss in Southeastern Allegheny County[M]. Youngstown: Youngstown State University, 2010.

[43] 张玲玲. 甘肃白龙江流域生态系统服务评估及影响因素[D]. 兰 州: 兰州大学, 2016. [Zhang L L. Ecosystem Services Assessment and its Driving Forces in the Bailongjiang Watershed of Gansu[D]. Lanzhou: Lanzhou University, 2016. ]

[44] 白永平, 王培安. 浙江省集聚经济类型的资源配置效应分析 [J]. 资源科学, 2012, 34(3): 510-519. [Bai Y P, Wang P A. Agglomerative economics' effects on resources allocation in Zhejiang province[J]. Resources Science, 2012, 34(3): 510-519. ]

[45] 万鲁河, 王绍巍, 陈晓红. 基于 GeoDA 的哈大齐工业走廊 GDP 空间关联性[J]. 地理研究, 2011, 30(3): 977-984. [Wan L H, Wang S W, Chen X H. GeoDA-based spatial correlation analysis of GDP in Hadaqi industrial corridor[J]. Geographical Research, 2011, 30(3): 977-984. ]

[46] Cliff A D, Ord J K. Spatial Autocorrelation [M]. London: Point Ltd, 1973.

[47] Anselin L. Local indicators of spatial association-LISA[J]. Geo- 
graphical Analysis, 1995, 27(2): 93-115.

[48] Altieri M A. The ecological role of biodiversity in agroecosystems [J]. Agriculture, Ecosystems and Environment, 1999, 74(1-3): 19-31.

[49] Zhang W, Taylor H R, Claire K, et al. Ecosystem services and disservices to agriculture[J]. Ecological Economics, 2007, 64(2): 253-260.

[50] Swinton S M, Lupi F, Robertson G P, et al. Ecosystem services and agriculture: cultivating agricultural ecosystems for diverse benefits[J]. Ecological Economics, 2015, 64(2): 245-252.

[51] 申卫军, 邬建国, 林永标, 等. 空间粒度变化对景观格局分析的 影响[J]. 生态学报, 2003, 23(12): 2506-2519. [Shen W J, Wu J $\mathrm{G}$, Lin Y B, et al. Effects of changing grain size on landscape pattern analysis[J]. Acta Ecologica Sinica, 2003, 23(12): 2506-2519. ]

\title{
Impact of landscape fragmentation on watershed soil conservation service a case study on Bailongjiang Watershed of Gansu
}

\author{
ZHANG Jinxi, LIU Dongqing, GONG Jie, MA Xuecheng, CAO Erjia \\ (Key Laboratory of Western China's Environmental Systems (Ministry of Education)/College of Earth and Environmental \\ Sciences, Lanzhou University, Lanzhou 730000, China)
}

\begin{abstract}
Bailongjiang watershed of Gansu, a vital water conservation area and environmental fragile area in the upper Yangtze River, is one of the four major landslides and debris flow disaster areas in China. Here, soil conservation service is particularly important. However, the highfrequency and high-intensity human activities have deepened the degree of landscape fragmenta tion and soil erosion in recent decades. Therefore, the research on the impact of landscape fragmentation on soil conservation service can clarify their spatial correlation and provide scientific basis for the watershed ecosystem sustainability. Taking Bailongjiang watershed of Gansu as an example, the spatio- temporal dynamic of landscape fragmentation and soil conservation service was quantitatively characterized from 1990 to 2014 via landscape pattern index, grid analysis, and InVEST model. Meanwhile, the relationship between the two issues was also discussed from the perspectives of mathematical and spatial statistics. The results showed that: (1) Initially, the degree of landscape fragmentation increased and then decreased in the Bailongjiang watershed in Gansu from 1990 to 2014. Soil conservation service documented a changing trend of descending firstly then ascending. (2) In 1990 2014, the spatial negative correlation between soil conservation service and landscape fragmentation developed from nothing to increase gradually. (3) By 2014, the degree of landscape fragmentation illustrated a significant negative impact on soil conservation service in the following areas: the northern part of Tanchang County, the middle and the southern part of Wudu District, the southern part of Wen County, and the boundary belts of Tanchang-Zhouqu-Wudu. It is essential to obtain a better soil conservation service through the decrease of the landscape fragmentation in the above areas.
\end{abstract}

Key words: landscape pattern; landscape fragmentation; soil conservation service; Bailongjiang Watershed of Gansu Province 